\title{
鋼管杭式栈橋に制震ダンパーを適用した 耐震補強工法の開発に関する実験的研究
}

\author{
宇野 州彦 1 三好 俊康 2 ・荒水 照夫 3 ・大塚 久哲 4 \\ 1 正会員 五洋建設株式会社 技術研究所（一329-2746 杤木県那須塩原市四区町 1534-1） \\ E-mail: Kunihiko.Uno@mail.penta-ocean.co.jp \\ 2 正会員 五洋建設株式会社 技術研究所（率329-2746 栃木県那須塩原市四区町 1534-1） \\ E-mail: Toshiyasu.Miyoshi@mail.penta-ocean.co.jp \\ 3 オイレス工業株式会社＼cjkstart免制震事業部（广326-0327 杤木県足利市羽刚町 1000） \\ E-mail: aramizu@oiles.co.jp \\ 4 フェロー会員 株式会社大塚社会基盤総合研究所（广814-0012 福岡県福岡市早良区昭代 3-6-23-601) \\ E-mail: orii.otsuka@mbr.nifty.com
}

民間事業者が保有する栈橋は地震対策の対応が遅れがちであるが，港湾法の改正により今後民間施設に おいても耐震補強工事の必要性が高まると思われる。しかし民間施設の耐震補強工事においては，施設を 供用しながら実施できる工法により施工する状況も考えられる。そこで著者らは橋梁等の分野で利用され ている制震ダンパーを栈橋に設置する耐震補強工法を考案し, 模型振動台実験においてその効果を把握す ることを本研究の目的とする.

実験結果から，橋梁等と同様に栈橋においても制震ダンパーで適切に地震エネルギーを吸収できること が示され，栈橋上部工の応答変位や杭に発生する断面力を大幅に低減でき，耐震補強工法として非常に有 効であることが示された。

Key Words : steel pipe piled pier, seismic control damper, seismic strengthening method, shaking table test

\section{1. はじめに}

港湾法の改正に伴い，水際の港湾施設（特定技術基淮 対象施設）を管理する民間事業者に対しては，港湾管理 者が維持管理の状況について報告を求めることや立入検 査, また必要に応じて勧告や命令の措置を講じることが 可能となる．そのため，今後民間施設においても而震補 強の必要性が高まってくるものと思われる.

また，港湾係留施設の中でも栈橋構造物は，地震時に おいて上部工の変形や杭の著しい損傷が生じると，その 後の供用は難しくなるため, 栈橋本体の構造的な而震補 強対策が求められる. 過去には兵庫県南部地震において, 神戸港の $\mathrm{T}$ 栈橋が被災し，栈橋が最大で約 $1.6 \mathrm{~m}$ 海側へ 変位した．その後の杭の引き抜き調査により，杭頭およ び杭中間部で座屈が生じていたことが明らかとなってい る. 原因としては埋立土と沖積砂層の液状化によって, 護岸が大きく海側へ変位し, 渡版を介して栈橋上部工に 荷重が作用したことと，地盤変位が地中部の杭に作用し たためと推定されている ${ }^{1)}$.

さらに而震補強の工法においては，施設を供用しなが
ら工事を実施できる工法が望ましい状況も考えられるた め，そのような工法開発が必要となってくる.

栈橋の耐震補強工法としてはストラット等を用いた 工法があるが，鋼材を用いた補強工法であるため，既存 の栈橋杭の強度が不足している場合は, 地震荷重に対応 寸ることが困難となる場合があると思われる，そこで著 者らは橋梁分野や建築分野で実績があり，また施設を供 用しながら設置することができる図-1 のような制震ダ ンパーを栈橋に適用する耐震補強工法を考案した。 制震 ダンパーは地震エネルギーを吸収することができるため, 強度の小さな栈橋杭においても十分な而震補強対策にな るものと考えられる. 本研究では, 制震ダンパーを適用 した而震補強工法の効果について, 模型振動台実験によ り把握することを目的とする.

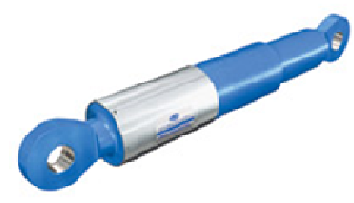

図-1 制震ダンパーの外観例 


\section{2. 実験概要}

\section{(1) 対象栈橋}

本研究で対象とする栈橋を図-2 に示す，本栈橋は昭和 40 年代に設計されたものであり, 現行基淮 ${ }^{1)}$ のレベル 2 地震動における而震性能は満足していない. 杭は鋼管で, 寸法は $\phi 914.4 \mathrm{~mm} \times 12.7 \mathrm{~mm}$ ，杭間隔は法線方向が $6 \mathrm{~m}$ ピ ッチ，法線直角方向が $5 \mathrm{~m}$ ピッチで配列されている．今 回は図中の赤枠で囲む範囲を実験模型対象とする.

\section{（2）実験模型および使用材料}

実験模型図を図-3に示寸，頁数の制約から，制震ダン パーを設置した場合の模型図のみを示す。本実験では, 対象栈橋を $1 / 4$ に縮尺して模型を製作した．縮尺した模 型寸法に関しては，土木研究所資料第 4023 号 ${ }^{2)}$ に基づく 相似則（表-1）を適用した。杭間隔は，法線方向 $1.5 \mathrm{~m}$, 法線直角方向 $1.25 \mathrm{~m}$ となる. また対象栈橋も含めて，一 般的に栈橋直下の地盤面は傾斜していることが多く，杭 の突出長が杭の配置場所によって異なってくる. 今回の 実験では，杭の突出長の変化を適切に表現するため，港 湾空港技術研究所資料 No.1267 ${ }^{3)}$ （図-4）を参考に，模 型杭よりも外径の一回り大きな鋼管 $(\phi 406.4 \mathrm{~mm} \times \mathrm{t} 9.5$ $\mathrm{mm})$ を模型杭下端に配置し，その鋼管と模型杭の二重管 構造部分の間隙にグラウト材を注入した. なおグラウト 材は，実験工程の関係から材齢 7 日で圧縮強度 100 $\mathrm{N} / \mathrm{mm}^{2}$ 以上発現する高強度グラウト材を用いた. グラウ 卜材打設から加振実験日までは 7 日以上の日数を確保し, 加振直前には現場養生しておいたグラウト材試験体の圧 縮試験, 静弹性係数試験を実施し, 圧縮強度で $100 \mathrm{~N} / \mathrm{mm}^{2}$ 以上の強度が出ていることを確認している．模型寸法お よび使用材料の一覧を表-2に示寸。

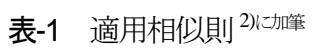

\begin{tabular}{|c|c|c|c|}
\hline \multirow[b]{2}{*}{ 物理量 } & \multirow[b]{2}{*}{ 静的実験 } & \multicolumn{2}{|c|}{ 振動台実験 } \\
\hline & & $\begin{array}{l}\text { 供試体によって支持 } \\
\text { された部構造あり }\end{array}$ & $\begin{array}{l}\text { 供試体によって支持 } \\
\text { された部構造なし }\end{array}$ \\
\hline 長さ & $\mathrm{S}_{\mathrm{L}}$ & $\mathrm{S}_{\mathrm{L}}$ & $\mathrm{S}_{\mathrm{L}}$ \\
\hline 時間 & - & $\mathrm{S}_{\mathrm{L}}{ }^{0.5}$ & $\mathrm{~S}_{\mathrm{L}}{ }^{0.5} \mathrm{~S}_{\mathrm{a}}^{-0.5}$ \\
\hline 振動数 & - & $\mathrm{S}_{\mathrm{L}}{ }^{-0.5}$ & $\mathrm{~S}_{\mathrm{L}}^{-0.5} \mathrm{~S}_{\mathrm{a}}^{0.5}$ \\
\hline 応力 & 1 & 1 & 1 \\
\hline 弹性倸数 & 1 & 1 & 1 \\
\hline 力 & $\mathrm{S}_{\mathrm{L}}^{2}$ & $\mathrm{~S}_{\mathrm{L}}{ }^{2}$ & $\mathrm{~S}_{\mathrm{L}}{ }^{2}$ \\
\hline 曲げモーメント & $\mathrm{S}_{\mathrm{L}}{ }^{3}$ & $\mathrm{~S}_{\mathrm{L}}{ }^{3}$ & $\mathrm{~S}_{\mathrm{L}}{ }^{3}$ \\
\hline 曲率 & $\mathrm{S}_{\mathrm{L}}{ }^{-1}$ & $\mathrm{~S}_{\mathrm{L}}{ }^{-1}$ & $\mathrm{~S}_{\mathrm{L}}{ }^{-1}$ \\
\hline 加速度 & - & 1 & $\mathrm{~S}_{\mathrm{a}}$ \\
\hline 上部構造質量 & - & $\mathrm{S}_{\mathrm{L}}{ }^{2}$ & $\mathrm{~S}_{\mathrm{L}}^{2} \mathrm{~S}_{\mathrm{a}}^{-1}$ \\
\hline 上部構造質量 & $\mathrm{S}_{\mathrm{L}}^{2}$ & $\mathrm{~S}_{\mathrm{L}}^{2}$ & $\mathrm{~S}_{\mathrm{L}}^{2}$ \\
\hline
\end{tabular}

表-2 実験模型の諸元

\begin{tabular}{c|l}
\hline 種 類 & \multicolumn{1}{c}{ 諸 元 } \\
\hline 模型杭 & $\phi 216.3 \mathrm{~mm} \times \mathrm{t} 4.5 \mathrm{~mm}, \mathrm{STK} 400$ \\
\hline 二重管部の鋼管 & $\phi 406.4 \mathrm{~mm} \times \mathrm{t} 9.5 \mathrm{~mm}, \mathrm{H}=500 \mathrm{~mm}, \mathrm{STK} 400$ \\
\hline 上部工 & $\square 2.1 \mathrm{~mm} \times 2.1 \mathrm{~mm}, \mathrm{~W}=130.4 \mathrm{kN}$ \\
\hline グラウト材 & セメント系無収縮モルタル, 材齢7日 :圧縮強度 $100 \mathrm{~N} / \mathrm{mm} 2$ 以上 \\
\hline
\end{tabular}

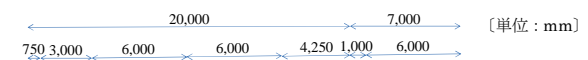

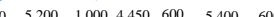

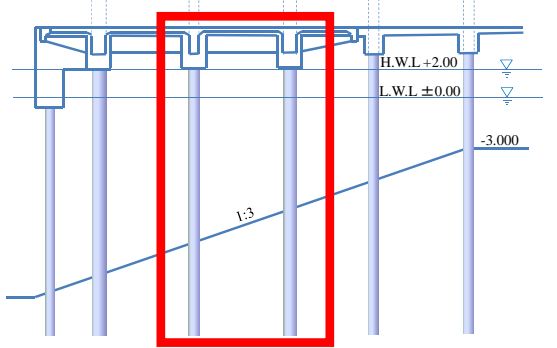

(a) 断面図

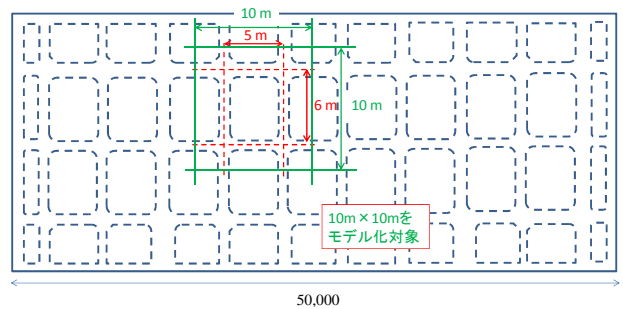

(b) 平面図

図-2 対象栈橋

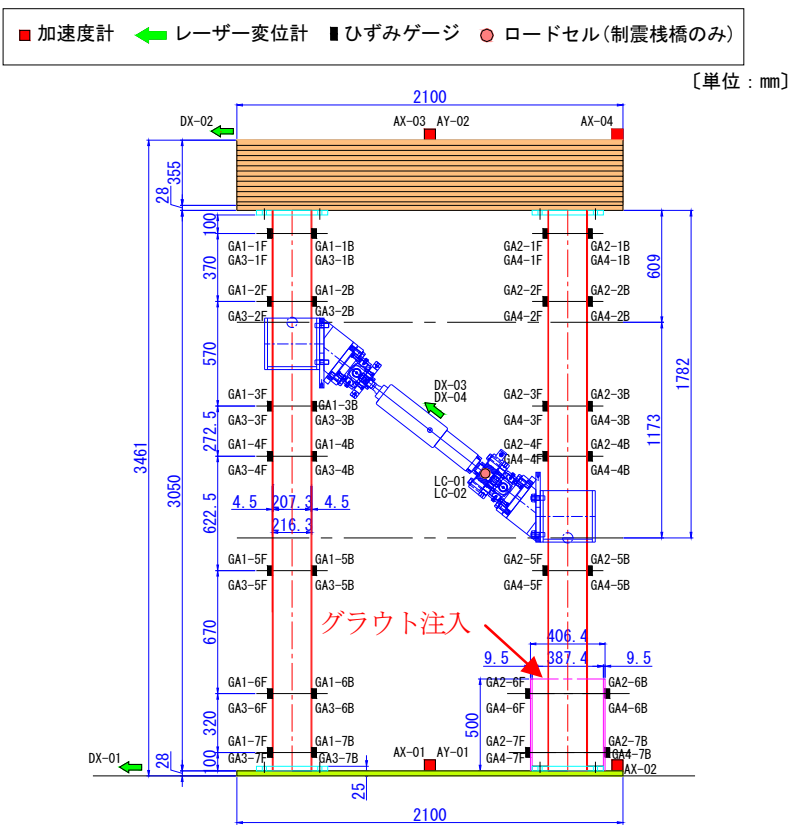

図-3＼cjkstart実験模型図（制震ダンパー設置栈橋）

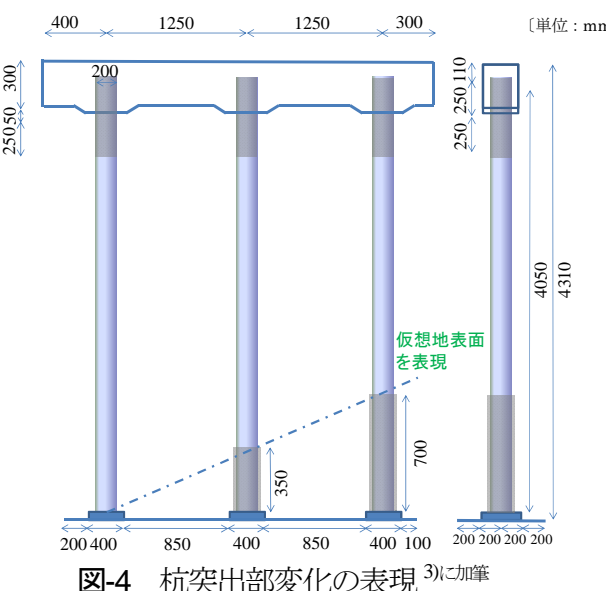

図-4 杭突出部変化の表現3)加䇛 


\section{（3）実験に用いる制震ダンパー}

実験で使用寸る制震ダンパーは，抵抗力 $100 \mathrm{kN}$ ，スト ローク $\pm 100 \mathrm{~mm}$ のタイプを使用した. 使用する制震ダン パーは, $\pm 0.03 \mathrm{~mm}$ 程度の小振幅時にもエネルギー吸収す ることを事前の性能試験で確認している．制震ダンパー には図-3 に示すように荷重計とレーザー変位計をあら かじめ取り付け，制震ダンパーに発生する荷重と変位を 直接計測できるようにしている.

また図-3 に示寸制震ダンパーの設置位置およびその 角度については, 事前に栈橋模型の解析モデルを作成し, 設置位置に関しては $20 \mathrm{~cm}$ ごとに配置高さを変えるパタ ーン，設置角度についても 10 度ごとに変化させるパタ ーンの組合せを複数ケース考え，それぞれについて地震 応答解析を実施し, 栈橋上部工の応答変位が最も小さく なるケースを採用した.

\section{(4) 計測項目}

計測器類の配置に関しては図-3に併記しているが，加 速度計は栈橋底版と栈橋上部工にそれぞれ 3 箇所設置し ている．平面的には，加振方向を計測する加速度計を平 板中央と端部，加振直角方向を計測する加速度計を平板 端部にそれぞれ配置している.これは，加振時にねじれ 等が発生していないかを確認するための配置である。

また，振動台と栈橋上部工，制震ダンパーを設置した 場合には制震ダンパーにそれぞれレーザー変位計を設置 した．栈橋上部工の変位を計測するための固定点を振動 台の外に設けているため, 栈橋上部工の相対変位を算出 するために振動台の応答変位も計測している.

模型杭にはひずみゲージを貼付し，杭に発生するひず みから曲げモーメントや軸力等の断面力を算出する. な お，杭下端の二重管部にもひずみゲージを貼付している が，これは二重管部において剛度が確保されているかを 確認するためのものである.

\section{（5） 入力地震動}

本実験で用いた入力地震動およびそのフーリエ振幅 スペクトルを図-5，図-6に示寸，時間軸は相似則 ${ }^{2)}$ に基 づいて実験用に圧縮している. 図-5 は兵庫県南部地震に おいてポートアイランドにてアレー観測された GL-79 m の地震波である (以下, PI-79 m と称す). 図-6 は平成 24 年に改定された道路橋示方書 ${ }^{4} に$ 記載されている TypeI-I-2 (平成 23 年東北地方太平洋沖地震 開北橋周辺 地盤上 EW 成分) の地震波である(以下，道示波と称す). 直下型タイプと海溝型タイプの 2 種類を採用した.

\section{3. 固有振動数試験}

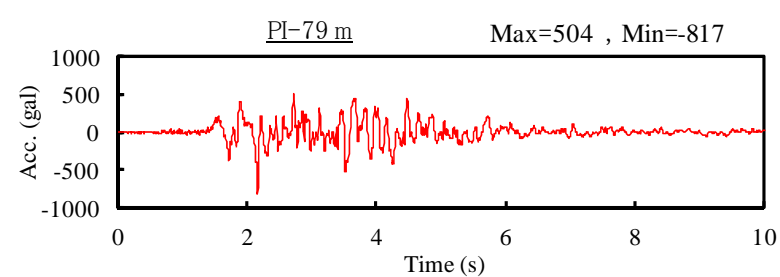

(a) 入力地震動

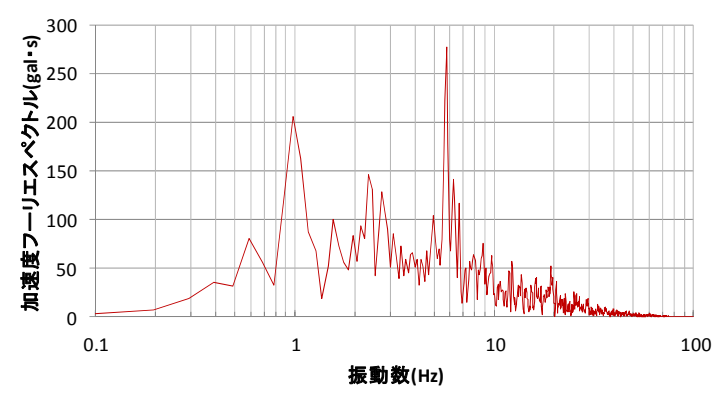

(b) フーリエスペクトル

図-5ＰI-79 m の入力地震動およびフーリエスペクトル

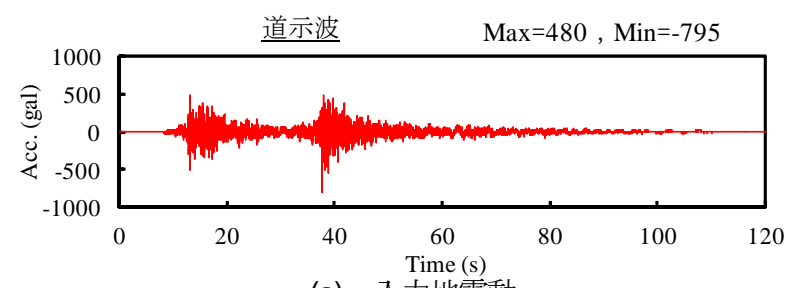

(a) 入力地震動

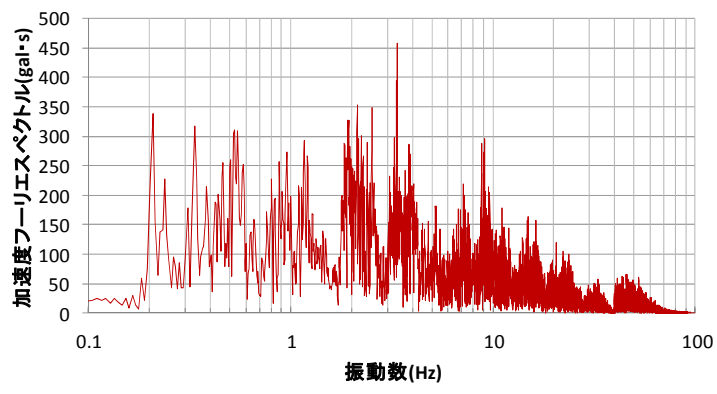

(b) フーリエスペクトル

図-6 道示波の入力地震動およびフーリエスペクトル

加振実験に先立って，栈橋模型の振動特性を把握する ために固有振動数試験を実施した．試験実施方法は掛矢 を用いて栈橋上部工に衝撃を与え，その後の自由振動を 計測する方法と，振動台にパルス波を入力し（最大加速 度 $150 \mathrm{gal}$ )，自由振動を計測する方法の 2 種類とし，両 手法による結果に大きな差異がないことを確認した上で, それぞれの結果の平均を採った。

試験の結果，制震ダンパーを設置していない栈橋（以 下，非制震栈橋と称す）は $2.55 \mathrm{~Hz}$, 制震ダンパーを設置 した栈橋（以下，制震栈橋を称す）は $4.92 \mathrm{~Hz}$ であった. 制震ダンパーを設置した制震栈橋は，制震ダンパーの初 期岡性の影響により固有振動数が増加したものと考えら れる. 


\section{4. 実験結果}

\section{(1) PI-79 m の加振結果}

a) 応答加速度時刻歴とフーリエスペクトル

図-7に栈橋上部工の応答加速度時刻歴を示寸. 図より 制震ダンパーを設置することで応答加速度が低減してい ることが分かる．また，図-8 はそれぞれの応答加速度の フーリエスペクトルを描いたものである. なお図-8 はス ペクトルの平滑化を行っており, Parzen ウィンドウを用 いバンド幅を $0.2 \mathrm{~Hz}$ としている. スペクトルのピーク振 動数は，非制震栈橋で $2.27 \mathrm{~Hz}$ ，制震栈橋で $4.76 \mathrm{~Hz}$ であ った．制震ダンパーによる地震エネルギー吸収について は後述するが，制震ダンパーを設置したことにより栈橋 の固有振動数が高くなったため, 入力地震動の卓越振動 数領域から外れることになり結果的に応答加速度が低減 したとも言える.

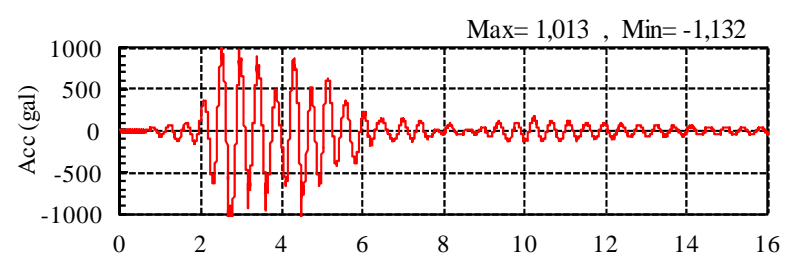

(a) 非制震栈橋

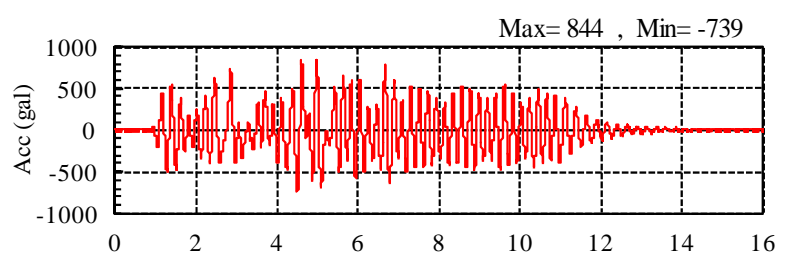

(b) 制震栈橋 $\mathrm{t}(\mathrm{s})$

図-7 栈橋上部工の応答加速度時刻歴

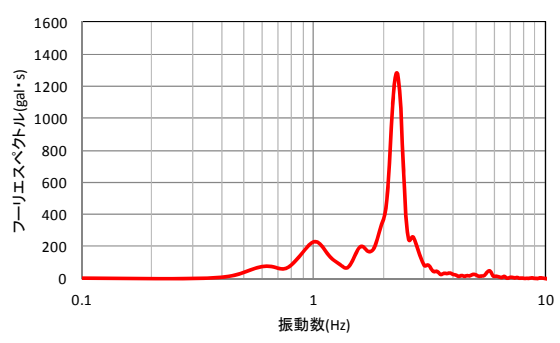

(a) 非制震栈橋

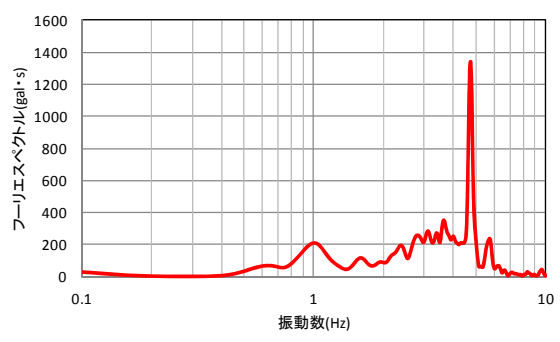

(b) 制震栈橋

図-8＼cjkstart応答加速度のフーリエスペクトル

\section{b) 応答変位時刻歴}

図-9 に栈橋上部工の応答変位時刻歴を示す．図より制 震ダンパーを設置することで, 変位量が最大で約 7 割程 度低減できており, 本工法が有効であることが示された。 また残留変位は, 非制震栈橋で $2 \mathrm{~cm}$ 生じていたものを 0 とすることができた.

c) 制震ダンパーの荷重一変位関係と等価減衰定数 heq

図-10に制震ダンパーの荷重一変位関係を示寸．制震 ダンパーの応答において履歴ループを描いていることか ら，地震エネルギーを吸収していることが分かる。また 履歴ループから算出した等価減衰定数 heq は 0.30 であっ た.

\section{d）杭に作用する曲げモーメント分布}

図-11に栈橋杭に発生する曲げモーメント分布を示寸。 非制震栈橋に着目寸ると，海側の杭 (突出長の長い杭) は杭頭部や杭下端部に大きな断面力が発生し，陸側の杭 （突出長の短い杭）は杭頭部に大きな断面力が発生して いる. これらの箇所においては, 降伏モーメントや全塑 性モーメントを超える断面力が発生しており，杭の損傷 が著しいものとなる。一方，制震栈橋においては，海側 の杭，陸側の杭のいずれにおいても曲げモーメントの值 は非常に小さく, 弾性範囲内の応答となっている. した がって，制震ダンパーを設置することで，杭の損傷を抑 制することができることが明らかとなった.

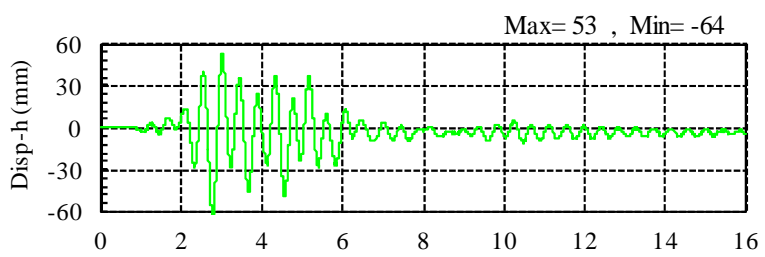

(a) 非制震栈橋 $\mathrm{t}(\mathrm{s})$

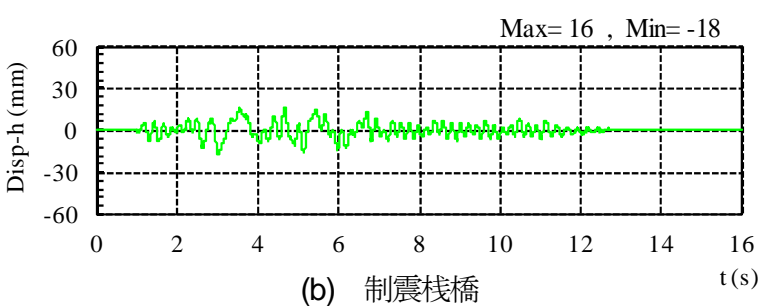

図-9 栈橋上部工の応答変位時刻歴

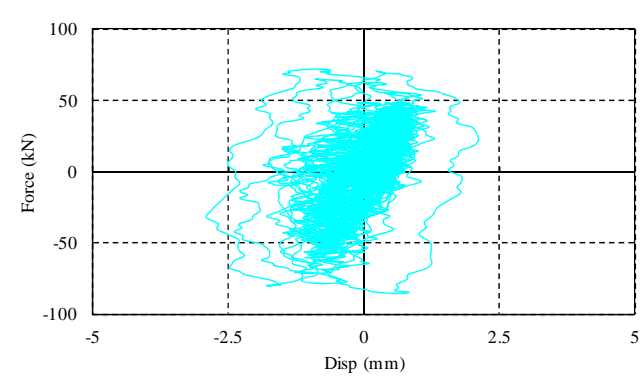

図-10 制震ダンパーの荷重一変位関係 


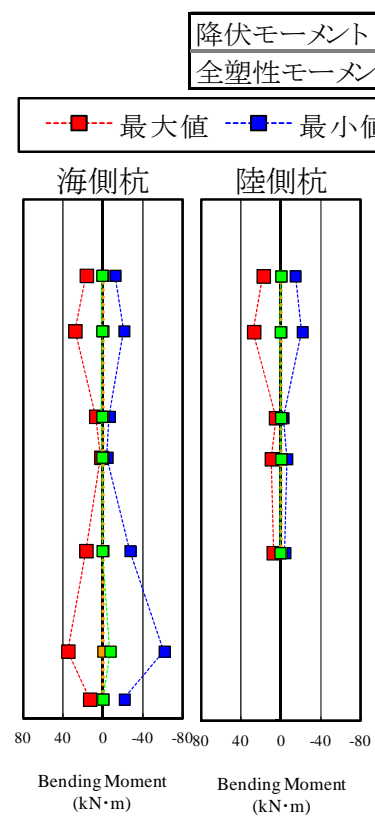

(a) 非制震栈橋

\section{$36.5 \mathrm{kN} \cdot \mathrm{m}$}

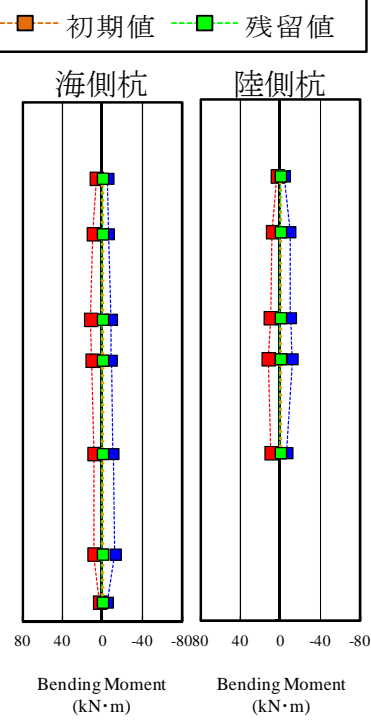

(b) 制震栈橋

図-11＼cjkstart栈橋杭の曲げモーメント分布

\section{（2）道示波の加振結果}

\section{a) 応答加速度時刻歴とフーリエスペクトル}

図-12 に栈橋上部工の応答加速度時刻歴を示す．PI-79 $\mathrm{m}$ 加振と同様, 制震栈橋において応答加速度が低減して いる. また，図-13 にそれぞれの応答加速度のフーリエ スペクトルを描いたものを示す．なお図-13 についても スペクトルの平滑化を行っており, PI-79 m 結果と同様 Parzen ウィンドウを用いバンド幅を $0.2 \mathrm{~Hz}$ としている. スペクトルのピーク振動数は, 非制震栈橋で $2.25 \mathrm{~Hz}$, 制 震栈橋で $4.76 \mathrm{~Hz}$ であった. 道示波の加振においても, 栈橋の固有振動数が入力地震動の卓越振動数領域から外 れることになり結果的に応答加速度が低減したと言える。 b) 応答変位時刻歴

図-14 に栈橋上部工の応答変位時刻歴を示寸，道示波 の加振においても, 制震栈橋に関しては非制震栈橋と比 較して, 変位量が最大で約 7 割程度低減できた。.また残 留変位についても, 非制震栈橋で $1 \mathrm{~cm}$ 生じていたものを 0 とすることができた.

c) 制震ダンパーの荷重一変位関係と等価減衰定数 heq

図-15 に制震ダンパーの荷重一変位関係を示す，道示 波でも同様に履歴ループを描いていることから，地震工 ネルギーを吸収できており，履歴ループから算出した等 価減衰定数 heq は 0.41 となった.

\section{d）杭に作用する曲げモーメント分布}

図-16 に栈橋杭に発生する曲げモーメント分布を示寸. 非制震栈橋に着目すると, PI-79 m 加振と同様, 海側の杭 の杭頭部や杭下端部，陸側の杭の杭頭部に大きな断面力 が発生しているが，制震栈橋においては，海側・陸側の いずれの杭も弾性範囲内の応答となり, 制震ダンパーの 而震補強効果が示された。

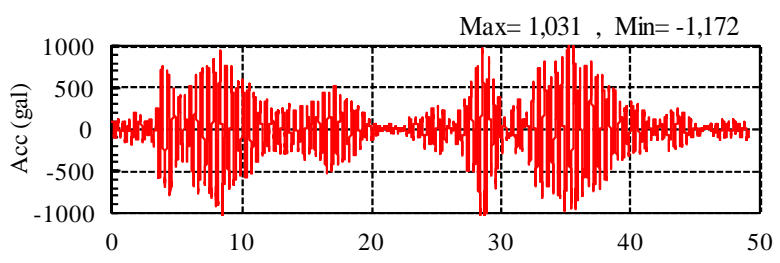

(a) 非制震栈橋

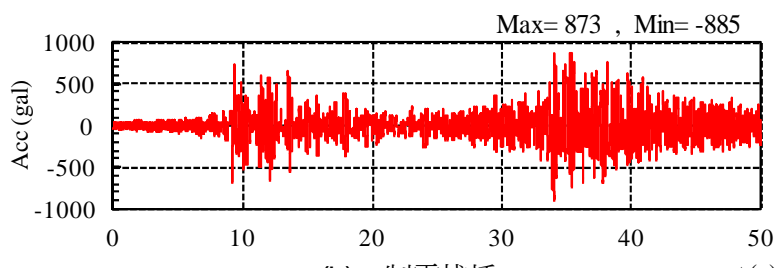

(b) 制震栈橋

図-12 栈橋上部工の応答加速度時刻歴

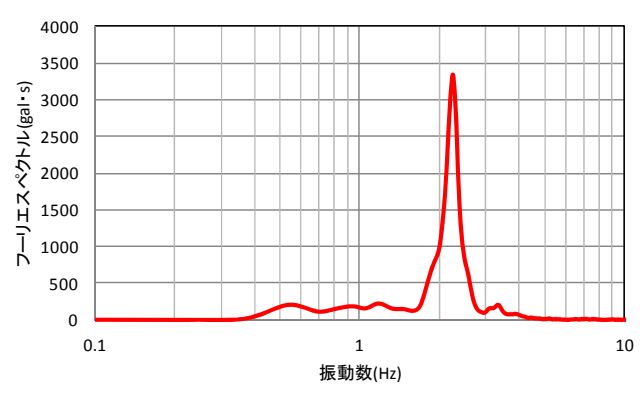

(a) 非制震栈橋

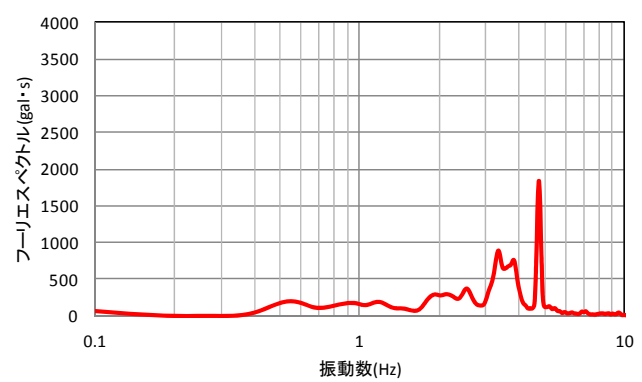

(b) 制震栈橋

図-13＼cjkstart応答加速度のフーリエスペクトル

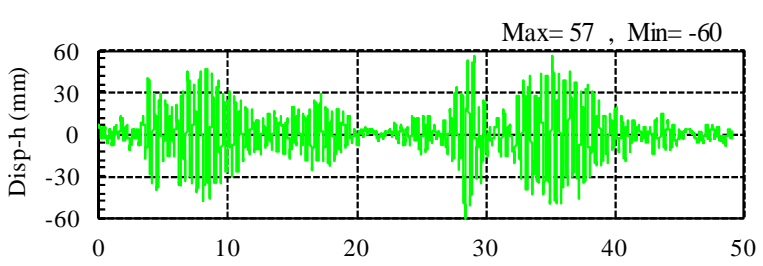

(a) 非制震栈橋

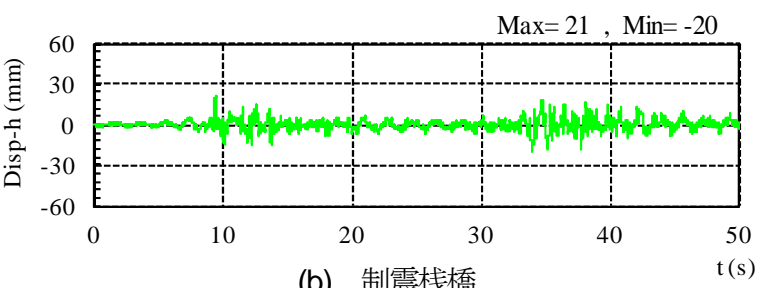

(b) 制震栈橋

$\mathrm{t}(\mathrm{s})$

図-14＼cjkstart栈橋上部工の応答変位時刻歴 


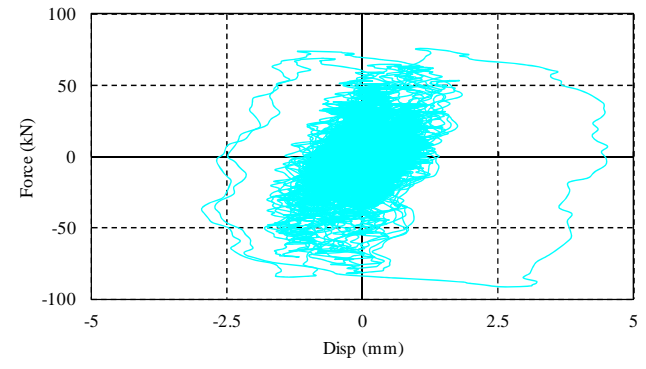

図-15 制震ダンパーの荷重一変位関係

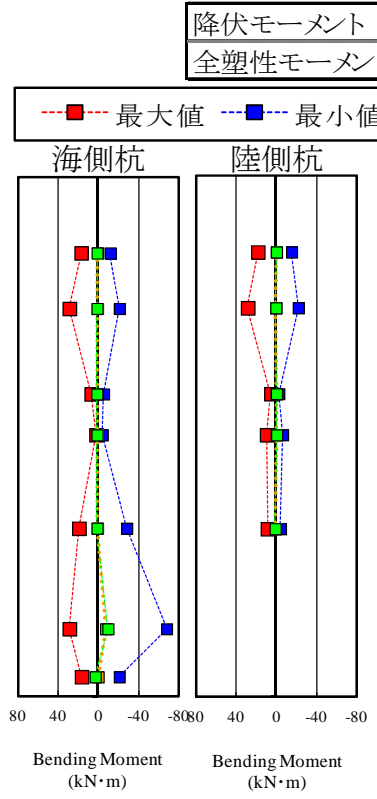

(a) 非制震栈橋

\begin{tabular}{ll|}
36.5 & $\mathrm{kN} \cdot \mathrm{m}$ \\
\hline $47.4 \mathrm{kN} \cdot \mathrm{m}$
\end{tabular}

---初期値 ---口--残留値

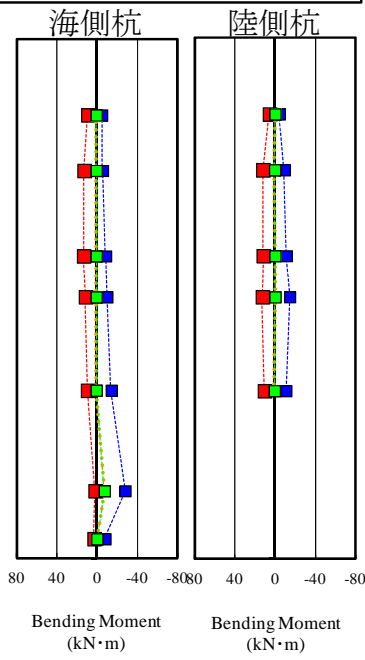

(b) 制震栈橋
図-16 栈橋杭の曲げモーメント分布

\section{5. まとめ}

栈橋の而震補強対策として，制震ダンパーを用いた工 法を考案し, 模型振動台実験を実施してその補強効果を 検討した. 実験結果から，2 タイプの地震動のいずれに 対しても, 栈橋構造物に制震ダンパーを設置することで, 地震エネルギーが吸収され，上部工の応答変位や杭に発 生する断面力を低減することができることが示された.

また，制震ダンパーの設置により栈橋全体の固有振動数
が増加し，それによって入力地震動の卓越振動数を回避 することができた. 場合によっては固有振動数増加によ り地震動の卓越振動数領域に近づくことも考えられるが, 構造物の変位量が大きくなることに伴い制震ダンパーの 作動量（変位）も大きくなり，その結果制震ダンパーで のエネルギー吸収量が大きくなるため, 結果として構造 物の応答が抑えられるものと考えられる。

今回の実験模型は，栈橋直下の仮想地表面より上方の 部分を抜き出し, 骨組み構造としての栈橋の挙動に着目 したものである。一般に，栈橋は渡版等を介して背後地 盤からの土圧伝達が行われない構造とするものであるた め, 本研究においては地盤変位の影響については考慮せ ず，慣性力が主たる影響を及ぼすものとして検討を行っ た. しかしながら，地震時に杭周辺地盤の変形が大きく なり，杭の地中部において著しい損傷が発生することも 考えられる. 今後の課題として，周辺地盤の影響を考慮 した上で，制震ダンパーを用いた工法が有効であること を示していく必要があるものと考えられる.

また本工法では，海水に晒される環境で制震ダンパー を使用するため，実用化に際しては腐食対策や海水の浸 入に対する対策が要求されるとともに，これらの定期的 な維持管理手法も必要となると考えられる，本論文で示 した耐震補強効果はもちろんのこと，これらの課題につ いても併せて検討を実施することが，実用化のためには 重要である。

\section{参考文献}

1) 南ら : 神戸港における横栈橋の被害調査と動的相互作用解 析, 第 24 回地震工学研究発表会, pp.693-696, 1997.

2) 運上ら : 橋の耐震性能の評価に活用する実験に関する ガイドライン（案）（橋脚の正負交番載荷実験方法及 び振動台実験方法)，土木研究所資料，No.4023，2006.

3) 川端ら：地震動により損傷した栈橋 RC 上部工の残存 性能評価，港湾空港技術研究所資料，No.1267，2013.

4) (公社) 日本道路協会 : 道路橋示方書・同解説 $\mathrm{V}$ 而震 設計編， 2012.

(2016.2.4 受付)

\section{EXPERIMENTAL STUDY ON DEVELOPMENT OF SEISMIC STRENGTHENING METHOD IN STEEL PIPE PILED PIER USING SEISMIC CONTROL DAMPER}

\section{Kunihiko UNO, Toshiyasu MIYOSHI, Teruo ARAMIZU and Hisanori OTSUKA}

According to the recent revision of Ports and Harbors Act, seismic strengthening works for privately owned jetties would be required, although their seismic countermeasure correspondence is still quite preliminary. The concept of seismic strengthening method is invented, in which the seismic control damper, utilized as seismic reinforcement for bridges, could be installed to piled pier. In this study, effect of damper is investigated by shaking table test of the experimental model in comparison with conventional pier. It is revealed that the damper absorbs a part of earthquake energy acted on the pier, seismic displacement of the superstructure and bending moment of the steel pipe are substantially reduced. 